\title{
On Chinese Government's Stock Market Rescue Efforts in 2015
}

\author{
Fanhua Zeng1, Wei-Chiao Huang'2, James Hueng2 \\ ${ }^{1}$ Zhongnan University of Economics and Law, Wuhan, China \\ ${ }^{2}$ Western Michigan University, Kalamazoo, Michigan, USA \\ Email: huang@wmich.edu
}

Received 4 March 2016; accepted 24 April 2016; published 27 April 2016

Copyright (C) 2016 by authors and Scientific Research Publishing Inc.

This work is licensed under the Creative Commons Attribution International License (CC BY). http://creativecommons.org/licenses/by/4.0/

(c) (i) Open Access

\begin{abstract}
The objectives of this paper are to provide a descriptive analysis of the Chinese stock market gyrations in 2015 and to assess the effectiveness of Chinese government's attempts to rescue the stock market from collapse. This paper views the efforts taken up by China's policy makers in 2015 to stabilize the stock market as a case study of public crisis management. We first briefly chronicle the boom and bust of China's stock market in the recent past seven months, and analyze the underlying causes and background of these gyrations. Next, we describe various policy actions implemented by the government in response to this public crisis. Finally, we provide some assessments and projections of the effectiveness of these intervention measures. We conclude that while it is understandable and seems necessary for the Chinese authority to intervene to prevent the crisis from exploding further, it has unfortunately damaged the credibility of the current leadership's management capability and resolve to "confine the power inside the cage".
\end{abstract}

\section{Keywords}

Chinese Stock Market, Market Stabilization Measures, Public Crisis Management

\section{Introduction}

China's stock market has been on a rollercoaster ride in the recent past seven months. Before peaking on June 12, 2015, China's stock market had ballooned about 150 percent in a year. Since then, China's stock market, as measured by the Shanghai Composite Index (A-share), has plunged about 35\%. When the sign of possible crashing in the stock market began to show, China's government responded actively in an attempt to stabilize stock prices. Various measures to support the market (some of them quite aggressive) have been implemented, such as suspending trading for a time on well over half of listed A-shares, banning short sales, forbidding major 
shareholders to sell stocks, disallowing new initial public offerings, etc. So far these measures do not appear to effectively prop up the markets to the target level. The implications and impacts of Chinese government's interventions have already been debated intensively among economists and public administration scholars.

This paper proposes to view the efforts taken up by China's policy makers as a case study of public crisis management. We briefly chronicle the boom and bust of China's stock market in the recent past seven months, and analyze the underlying causes and background of these gyrations. Next, we describe various policy actions implemented by the government in response to this public crisis. Finally, we provide some assessments and projections of the effectiveness of these intervention measures.

\section{The Bursting of the Bubble and Subsequent Gyrations}

Before peaking on June 12, 2015, China's stock market had ballooned about 150 percent in a year. The Chinese stock market crash began with the popping of the stock market bubble in mid-June (starting on June 15, 2015). A third of the value of A-shares on the Shanghai Stock Exchange was lost within one month following the event. The Bank of England gave a frightening illustration of the enormous scale of the Chinese stock market rout, stating that the \$2.6 trillion wiped off the Shanghai and Shenzhen Composite indexes in the initial 22-day summer market rout is equivalent to the entire GDP of the UK in 2013, and amounts to seven and a half times the nominal value of outstanding Greek government debt. The carnage did not end in 22 days. Major (more severe) aftershocks occurred around July 27 (the Shanghai Composite Index fell by 8.5 percent, marking the largest fall since 2007) and again on August 24 "Black Monday" (8.5\% fall in the Shanghai Composite Index) and August 25 "Black Tuesday" (another 7.6\% fall). As of this writing, as can be seen in the following charts (taken from http://www.marketwatch.com/investing/index/SHCOMP/charts?CountryCode=cn) the market seems to have calmed down with the index hovering around 2900 points (compared to 5178 peak reached on June 12). However, this relative quietness, along with shares languishing in their lows and low trading volume and volatility, shows that the market is now left in the doldrums, and is likely to be stuck for a long time. Altogether, last summer's herd stampede has practically erased the Chinese stock market's gains in the first half year of 2015 completely (Figure 1 and Figure 2).

\section{Causes of China's Stock Market Crash in 2015}

The source of any stock market crash may vary over specific circumstances [3]-[6], but one general reason remains generically the same: What goes up must come down. Thus we need to understand what cause the bubble in China's stock market to form (buying frenzy) and pop (panic selloff). Between June 2014 and June 2015, China's Shanghai Composite index rose by 150 percent. There was strong sign that the seemingly bull market was actually entering the bubble territory as it is not justified or consistent with the economic fundamentals. The value of many shares rose at a rate and speed that made little sense. Many companies with meager earnings (or even losses) were seeing a meteoric rise in their shares. Meanwhile, the country's broader economy was going the other way, with economic growth slowing down significantly (the economic growth rate has fallen from double digit figure in previous years to 7\%, dubbed the "New Normal" by Xi-Li leadership.) In other words, in a healthy market, stock market booming usually signals an economic expansion. But the Chinese economic growth has been declining in the past few years and was not expected to go back to the brisk growth in the near future. Therefore, the 2014-2015 run-up was clearly a bubble without support from the real economy.

A big reason for the stock market rally was that a lot of ordinary Chinese people began investing in the stock market for the first time. More than 40 million new stock accounts were opened between June 2014 and May 2015. Unlike other major stock markets, which are dominated by professional money managers, retail investors account for around 85 percent of China's trade. “A majority of the new investors in China's market don't have a high school education (6\% are illiterate). There are now more retail investors in the Chinese stock market (90 million) then there are members of China's Communist Party (88 million)", as reported by Reuters. These inexperienced retail investors dramatically increased the volatility of the market leading to much greater fluctuations in stock market than would otherwise be the case. This is because they, unlike institutional investors who are professionals engaging in long-term investments on the basis of rational market analysis and projections, typically engage in short-term speculations based on hearsays, rumors and irrational projections. As a result, they tend to exhibit herd behavior causing much greater share price fluctuations than would otherwise be the case.

Worse yet, many of these novice investors were making highly leveraged purchases with borrowed money. 
F. H. Zeng et al.

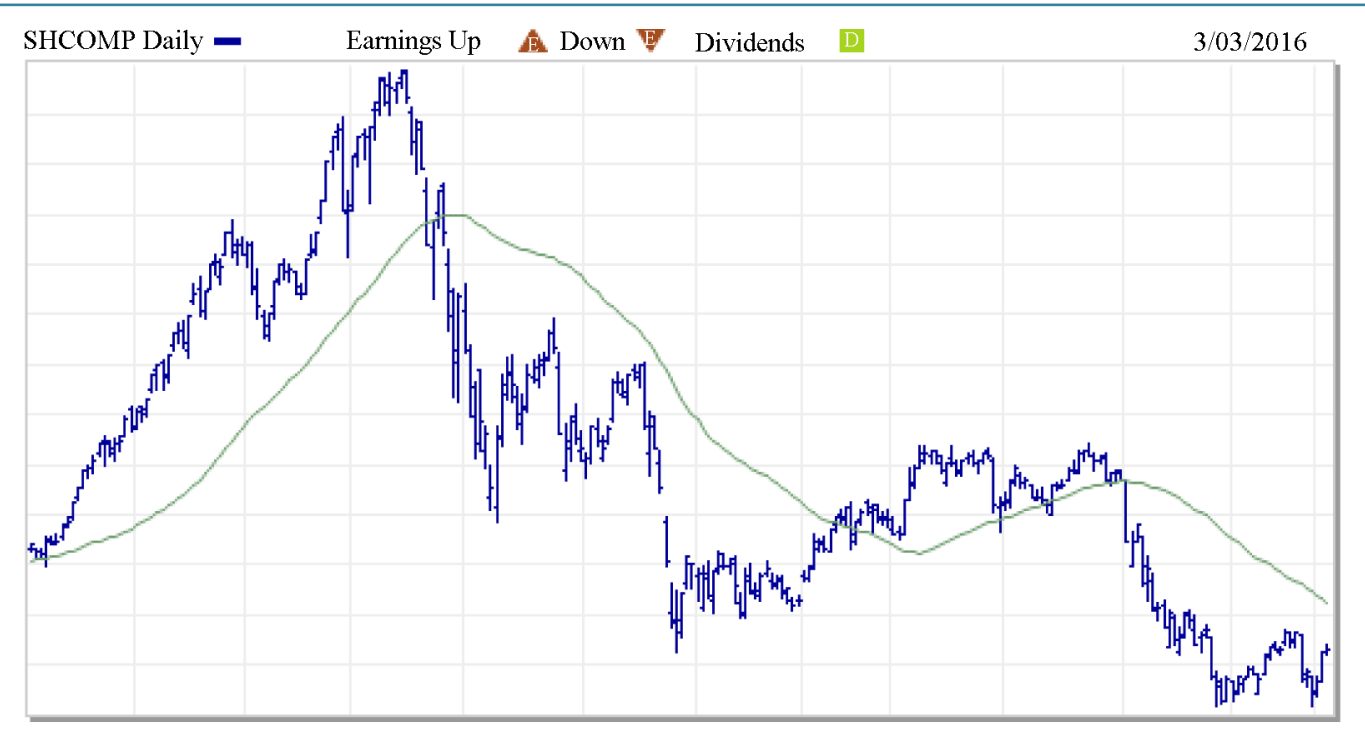

5,200

5,000

4,800

4,600

4,400

4,200

$, 4,000$

3,800

3,600

3,400

3,200

3,000

2,800

2,600

Volume -

BigCharts.com

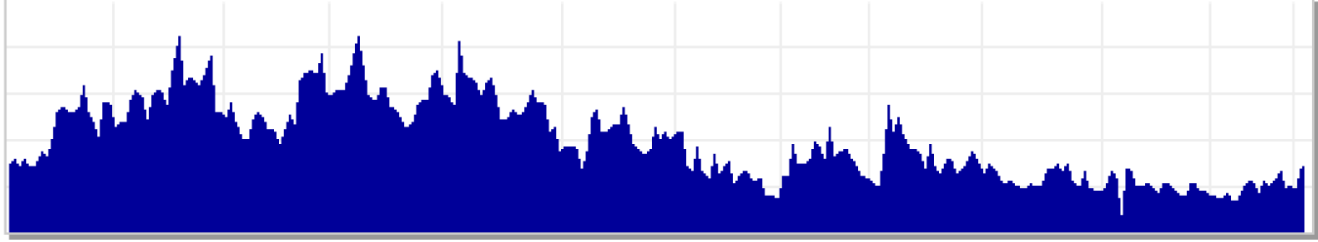

0.8

0.6

0.4

高

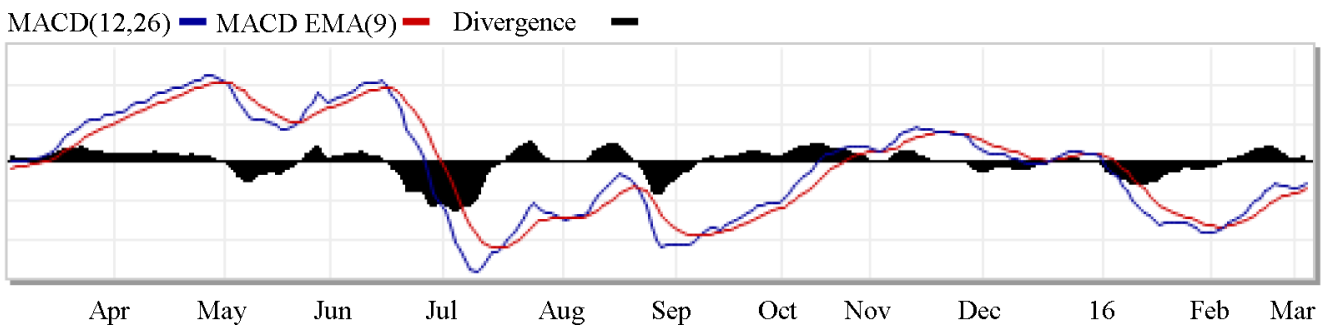

Figure 1. Shanghai composite index. Source [1]:

http://www.marketwatch.com/investing/index/SHCOMP/charts?CountryCode=cn.

Shanghai Composite's rock 'n' roll

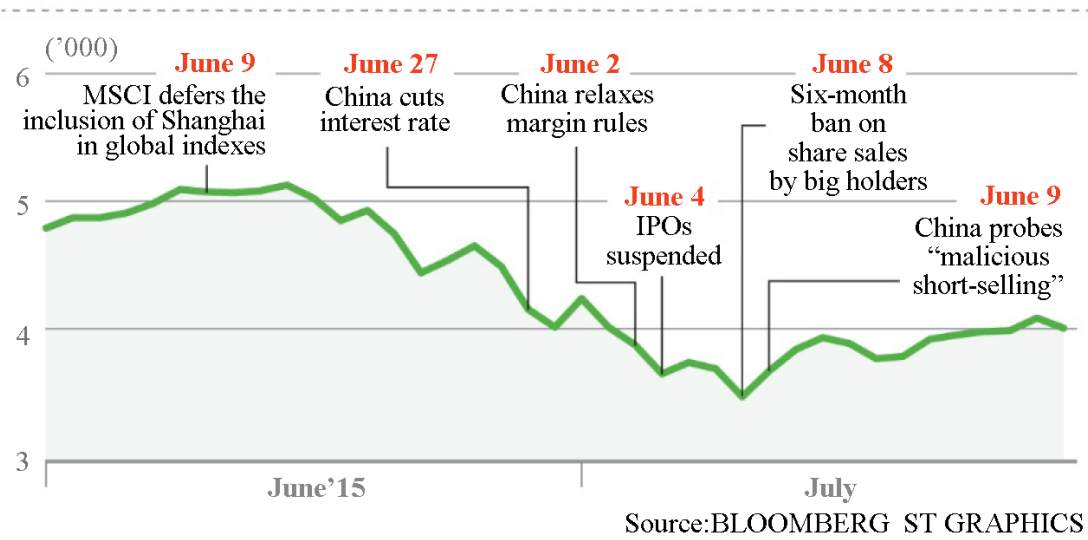

Figure 2. Shanghai composite index volatility and policy actions. Source: Goh, E.Y. [2]. 
This practice, known as "trading on margin”, used to be prohibited in China. But then the Chinese government lifted the prohibition changing policy to strictly regulate the practice of margin trading. Over the past five years the Chinese authorities have gradually relaxed the restrictions on margin trading. The newly relaxed rules still included an important safeguard, though: a 2-to-1 margin requirement said that only half of invested funds could be borrowed. The investor needed to put up the rest of the funds herself. There were also restrictions on which stocks you could buy and how long the money could be borrowed - rules designed to prevent speculative mania from getting out of hand. However, people also found a number of creative ways to evade these requirements. As a result, many people have been able to make even riskier bets than the official rules allowed.

The borrowed money flooded into the Chinese stock market between June 2014 and June 2015, helping to push stock prices up 150 percent. During this period, the amount of officially sanctioned margin trading in the Chinese stock market ballooned from 403 billion yuan to 2.2 trillion yuan. Experts estimated that another 2 trillion yuan or so of borrowed money has flowed into the markets using vehicles designed to skirt official limits on margin trading. So, margin trading — and margin debt—skyrocketed, and a perfect storm was forming.

The surge in stock prices alarmed Chinese authorities. Earlier this year they took steps to rein in margin trading and other forms of leveraged investing. In January, they raised the minimum amount of cash needed to trade on margin. They also punished a dozen companies for failing to enforce rules on margin trades. In April the government cracked down on vehicles designed to skirt the margin trading rules. The government's toughest measures came on Friday June 12, when China's securities regulator announced a new limit on the total amount of margin lending stock brokers could do, while also reiterating the curbs on illicit margin trading. Looking back, this announcement acted as a last straw and triggered the market to fall on the following Monday. When the market nose-dived, investors faced margin calls on their stocks and many were forced to sell off shares in droves, precipitating the crash further. Now the bubble has popped.

So on surface, it looks as though the retail investors are to be blamed for their own irrational exuberance that caused the crash. But beneath the surface the Chinese government is not without fault (if not to be faulted as the culprit, at least to be blamed for mismanagement). The crash also reflects the underlying structural problems of the economy. In the recent past years (especially since the 2008 great recession), Beginning in the early 1990s China has achieved two decades of remarkable double-digit growth. But it is increasingly clear that this export and investment led growth is not sustainable without substantial restructuring and rebalancing of the economy. Then came the 2008 great recession, causing global demand to fall precipitously and China could no longer keep its growth going through exports. And its own citizens weren't consuming enough to create the demand necessary to keep the growth engine revving either. The Chinese government's answer was to mount a massive stimulation package, using monetary policy, state-owned banks, local governments, and other tools under its control to push internal investment. The result was a massive buildup in factories, highways, airports, real estate, and much more. Some of these investments were wise. Many weren't. China has become famous for its profusion of empty stadiums, skyscrapers, and ghost cities. The result is a lot of overcapacity and many state-owned enterprises and local governments are ridden with enormous bad debt. This is part of why the Chinese government encouraged the stock market boom. As said by an analyst, "The Chinese government basically comes up with this plan. They see they have these heavily indebted companies that need to raise money to clean up their balance sheets. They realize there are these huge savings in China that can be put into the stock market. So they begin talking up the stock market and they make it easier to use margin debt. And margin debt exploded.”

In a sense, the stock market boom was caused by government's strategy to solve the debt problem of zombie state-owned enterprises and the government's (China Securities Regulatory Commission) facilitation of margin trading by relaxing the previous restrictions. This coincided with the timing when the Chinese property market went down, and people who were putting their money in property began looking elsewhere for better returns. Lots of novice investors got into the stock market because the Communist Party, in word and deed, was pushing them into a debt-fueled binge in the stock market. State media also played a prominent role in drumming up the stock market bubble in the first place. The official Xinhua News Agency published eight articles on the stock market in a space of three days in early September 2014 to solicit investors joining the historic gambling, and in March 2015, the CCP's mouthpiece People's Daily issued a three-article series, "A Share Volatility [Is Part of] a Slow Bull; [Index] Expected to Challenge 4000.” As the Economist puts it, "The government got all of the corporations in China that were going broke to go public. Then, they got the average Chinese citizen to invest." and "Officials are seen to have promised the population a bull market, only to lure them into a bear trap" (quoted by James Richards in his blog posted on August 10, 2015 at Daily Reckoning.com). 


\section{Government's Response to Rescue the Market}

The Chinese government enacted many measures (more than 40 and counting) to stem the tide of the crash. Regulators limited short selling under threat of arrest. Large mutual funds and pension funds pledged to buy more stocks. The government stopped initial public offerings. The government also provided cash to brokers to buy shares, backed by central-bank cash. State-run media continued to persuade its citizens to purchase more stocks. In addition, China Securities Regulatory Commission (CSRC) imposed a six-month ban on stockholders owning more than 5 percent of a company's stock from selling those stocks. Further, around 1300 total firms, representing 45 percent of the stock market, suspended the trading of stocks starting on July 8.

The following is a chronological listing of all the different policy buttons China has pressed on its financial crisis console since stocks started unraveling after mid-June (Most of this list is compiled by analysts at Bank of America Merrill Lynch as reported by Ben Moshinsky on August 27, 2015 at http://www.businessinsider.com, with additional updates by the authors).

\section{June 27}

1) China's central bank, People's Bank of China, cuts interests rate by $0.25 \%$.

\section{June 30}

2) Asset Management Association of China (AMAC) requests investors and fund managers to stay rational and not to panic.

\section{July 2}

3) Brokers loosen margin financing requirements; the practice of lending to retail investors who use the money to trade shares.

4) State Council decides to suspend large public share offerings until Shanghai Composite Index of shares returns to 4500 level.

5) Police investigate three media outlets for spreading rumors and the government vows to impose heavy penalties for manipulation. Government-run news sources Xinhua and People’s Daily both publish articles calling for investors' confidence.

\section{July 3}

6) Margin financing: some brokers lower threshold and loosen policy again.

7) Crackdown on short selling and several brokers suspended the business.

\section{July 6}

8) China Financial Futures Exchange (CFFEX) restricts index future trading.

9) China Securities Finance Corporation (CSFC) to use funds contributed by various brokers to buy exchange traded funds. Social Securities Fund (SSF) vows not to reduce existing equity positions in its portfolio.

July 7

10) China Insurance Regulatory Commission (CIRC) allows insurers to invest more in blue-chip stocks.

July 8

11) $\mathrm{PBOC}$ vows to maintain market stability and avoid systematic financial risk. It will provide ample liquidity to CSFC via interbank lending, financial bond, pledged financing, and relending facilities.

12) CSFC grants credit to 21 brokers via pledged stocks to allow them to buy more equities.

13) CSFC invests in mid cap stocks via mutual funds.

\section{July 9}

14) China Securities Regulatory Commission (CSRC) suspends reviews of share offerings.

15) China Banking Regulatory Commission (CBRC) allows banks to roll over matured loans pledged by stocks.

16) Minister of Public Security \& CSRC investigates "malicious" short selling activities.

17) CSFC says it will purchase mutual fund products to stabilize liquidity.

\section{July 13}

18) CSRC probes trading system vendor Hundsun Tech for allowing illegal margin financing.

19) China tightens rules on futures trading.

July 15

20) CSDC to extend business hours for major shareholders to increase their own companies' stock holdings.

July 16

21) CSRC demands brokers' proprietary trading to maintain net purchase on daily basis and it will allow bro- 
kers equity investment to exceed risk limit during special period.

July 17

22) CSFC receives RMB 1.3 trillion from 17 commercial banks.

July 20

23) CSRC clarifies that government money will not be exiting the stock market.

July 27

24) CSRC denies rumor that state buying has stopped.

July 30

25) CSFC grants Rmb200 billion liquidity to five mutual funds.

26) CIRC urges insurers not to net sell equities in near future and demands daily report on equity holdings.

27) China Securities Depository and Clearing Co., Ltd. (CSDC) cuts fees.

\section{August 3}

28) CSRC investigates electronic trading; 24 funds suspended for 3 months.

29) Shanghai Stock Exchange (SHEX) and Shenzhen Stock Exchange (SZEX) significantly raise commission to discourage program trading.

30) Policy banks announce RMB 1 trillion bonds to support infrastructure and construction in coming years.

31) Stock markets change settlement dates to discourage speculative short-selling and to mitigate intraday volatility.

\section{August 7}

32) Speculation that CSFC has war chest of RMB3 trillion to invest in stock market.

33) CSRC vows to crack down on margin financing and illegal short selling.

\section{August 11}

34) PBOC adjusts currency fix, devaluing by $3 \%$. Four out of five of the CSFC-invested mutual funds have started investing in A-share stock market.

\section{August 14}

35) CSFC publishes its exit plan: Part of its stock holding will be transferred to Huijin; CSFC says it won’t exit the stock market over the next few years.

36) Ministry of Finance (MOF) relaxes rules for state-owned venture capital funds.

August 18

37) CSRC investigates HOMS and Hithink Royalflush for illegal lending to finance retail stock purchases (margin financing).

\section{August 21}

38) CSRC suspends approval of 191 mutual funds and seeks to encourage more risk-tolerant investors.

\section{August 23}

39) State Council issues new pension fund investment guidelines, allowing stock investment at $30 \%$ of net assets.

\section{August 25}

40) Chinese central bank PBOC cuts interest rates by $0.25 \%$.

\section{September 7}

41) Ministry of Finance (MOF) said it would remove personal income tax on dividends for shareholders who hold stocks for more than a year.

\section{October 24}

42) Chinese central bank PBOC cuts interest rates by $0.25 \%$.

\section{Assessment of Policy Effectiveness and Implications}

Despite the myriad of measures mentioned above that were taken by China's policymakers in their attempt to "rescue" the market, the authorities have failed to prop up the stock market prices. By the end of August, it appears that the government has abandoned initial plans to boost stocks up to their self-proclaimed mandate level of 4500 points. While it may be still too early to give an " $F$ " grade to the Chinese government's performance in this case study of public crisis management, suffice to say that up to now they have not effectively managed to solve the problem. Most of those measures mentioned above have not really worked. Some of these policies such as the interest rate cuts, loosening rules on pension fund investing, and banning short selling look more like the result of hastily formed (out of panic) rather than carefully thought out policies. There's only one thing that 
seems to have a real effect: the direct stock purchases through the government's so-called "national team".

The "national team" is the collective name given to state-backed and state-directed Chinese financial firms who have been ordered to directly buy stocks in an attempt to boost investor confidence. As the name suggests, these firms work in tandem to push share prices higher. So far the "national team" has not been successful in pushing share prices higher to the targeted level of 4500 points, but at least it has been widely credited for helping to prevent even greater market losses. The working of the "national team" is evident in many intraday transaction activities: when the market starts to decline "abnormally" showing a sign of wild selloff, there will be mysterious surge of large volume purchases hinting that the "national team" is entering the market. This "national team" staged rally typically occurred in the last hour of trading before the markets close. Just how much money has the "national team" put towards stocks over the past three months? According to Goldman Sachs analysts, it's a near-unbelievable 1.5 trillion yuan, or \$US236 billion. Given that the market capitalization of Amazon is around \$US236 billion, this means that China has spent the entire Amazon market capitalization to prop up its stock market, an extremely expensive policy-making on the part of the Chinese government.

Cost-effectiveness issue of policy-making aside, the market rescue actions also have profound implications. Above all, the incessant meddling in the nation's stock market, which borders on outright market manipulation, is an irony of trying to save the market but ending up with harming (if not killing) the market. The authorities used several draconian tactics such as banning some investors from selling, investigating those who still choose to sell and arresting those who have sold shares "maliciously", and even detaining and forcing the journalist to apologize on state television for reporting ("spreading the rumor") that CSRC was preparing an exit plan from outright share purchases. These tactics may prevent market melt-down in the short term, but will chill the market in the long term, and also have the side effect of moral hazard and market distortion. Some bold scholars inside China also criticize government's handling of this matter. For example, Yongding Yu, the Director of the Institute of World Economics and Politics at the Chinese Academy of Social Sciences, said "The current stock market unrest does not constitute a systematic crisis, and so the government should not intervene. What is happening to China's stock market now is not panic selling but a re-evaluation of the prices. It is inevitable that there is some overshooting in this process, but the government should not take the place of the market and put prices on stocks” (The New York Times, Sept. 14, 2015).

On the other hand, a classic market failure argument can be made in defense of the Chinese government's actions: when the market fails to function properly, government intervention is justified. Clearly China's stock market was not functioning properly in the past 10 months and market correction is inevitable. Some would even argue that China's stock market is not a capital market like the capital markets in U.S., Japan and Europe, it is essentially a casino! So this is not a market intervention but a gaming regulation and restoration of order. Besides, there are precedents of urgent government intervention in other places of the world, such as the massive infusion of liquidity and rescue efforts by U.S. government in response to the 2008 financial crisis. In addition, this stock market turmoil is not just an economic issue, if not dealt with it could become a broader political problem of governance and leadership legitimacy, considering the anger and potential social unrest resulting from evaporation of fortunes of more than 80 million individual investors.

\section{Conclusion}

In conclusion, China's stock market bubble popped in mid-June. For various reasons (justifiable or not), China's government mounted massive measures attempting to stop the plunge of the stock market in the summer of 2015. So far, despite the many aggressive rescue efforts, the carnage has practically erased the Chinese stock market's gains in the first half year of 2015 completely. While recently the market seems to have calmed down, it is difficult to determine for sure if this means that market correction is complete and tentative equilibrium is reached. It is quite likely that it is not out of the woods yet. Chinese leader Xi Jinping had promised since 2013 to let market forces play a larger role in the economy, but the stock market turmoil over the past couple of months has forced the authorities to retract from that intention, intervening heavily to prevent a bigger crash. This is a setback from the course of reforms envisioned by the Chinese government. It also costs the Chinese government credibility and shakes faith in its ability to form and execute coherent policy.

\section{References}

[1] Shanghai Composite Index: http://www.marketwatch.com/investing/index/SHCOMP/charts?CountryCode=cn 
[2] Goh, E.Y. (2015) China’s “Desperate” Stock Market Rescue Was Necessary. Caijin, July 25, 2015.

[3] Huang, W.C. and Zhu, Y.L. (2004) Are Shocks Asymmetric to Volatility of Chinese Stock Markets. Review of Pacific Basin Financial Markets and Policies, 7, No. 3. http://dx.doi.org/10.1142/S0219091504000159

[4] Hueng. J.C., et al. (2014) Choosing between Value and Growth in Mutual Fund Investing. Financial Services Review, 23, 341-359.

[5] Hueng, J.C. and Huang, P. (2009) Interest-Rate Risk Factor and Stock Returns: A Time-Varying Factor-Loadings Model. Applied Financial Economics, 19, 1813-1824. http://dx.doi.org/10.1080/09603100903049674

[6] Hueng, J.C. (2006) Short-Sales Constraints and Stock Return Asymmetry: Evidence from the Chinese Stock Markets. Applied Financial Economics, 16, 707-716. http://dx.doi.org/10.1080/09603100500426697 